\title{
FAKTOR PENYEBAB SISWA YANG TERISOLIR STUDI KASUS DI SMK PGRI 1 PALEMBANG
}

\author{
Febri Ika Putra ${ }^{1}$, Evia Darmawani ${ }^{2}$, Ramtia Darma Putri ${ }^{3}$ \\ Universitas PGRI Palembang ${ }^{1}$ \\ Email: febriip04@gmail.com \\ Universitas PGRI Palembang ${ }^{2}$ \\ Email: eviadarmawani@gmail.com \\ Universitas PGRI Palembang ${ }^{3}$ \\ Email: tyadhuarrma27@gmail.com
}

\begin{abstract}
ABSTRAK
Tujuan penelitian ini adalah untuk mengetahui faktor penyebab siswa " $R$ " yang terisolir di SMK PGRI 1 Palembang. Metode yang digunakan dalam penelitian ini yaitu kualitatif dengan teknik pengumpulan data. Objek penelitian ini adalah siswa " $R$ " kelas XII Akuntansi 2 SMK PGRI 1 Palembang. Teknik pengumpulan data menggunakan wawancara dan dokumentasi. Hasil penelitian menyimpulkan bahwa siswa yang terisolir cenderung akan menarik diri dari lingkungan pergaulan teman sebayanya disebabkan oleh kemampuan bersosialisasi yang rendah. Siswa yang terisolir lebih sering menghabiskan waktu menyendiri, kurang aktif dan pendiam di kelas serta tidak bisa berpartisipasi dalam kegiatan kelompok, ini akan menyebabkan siswa tersebut merasa mider dan tidak percaya diri akibatnya siswa menjadi terisolir dan menarik diri dari lingkungan pergaulan teman sebayanya. Adapun faktor penyebab siswa " $R$ " terisolir yaitu memiliki hambatan dalam berkomunikasi serta tidak terbiasa bersosialisasi dengan lingkungan sekitar, akibatnya siswa " $R$ " menarik diri dari lingkungan pergaulan teman sebayanya serta tidak mempunyai minat untuk mengikuti kegitan-kegiatan kelompok sebagai proses sosial.
\end{abstract}

Kata Kunci : Faktor Penyebab, Siswa, Terisolir

FACTOR IN THE CAUSES OF ISOLATED STUDENT STUDIES AT SMK PGRI 1 PALEMBANG

\begin{abstract}
The purpose of this study is to know the factors underlying " $r$ " students who are isolated at SMK 1 palembang. The methods used in this study are qualitative with data collection techniques. The object of this study is " $r$ " class xii, accounting 2 smgri 1 palembang. Data collection techniques using interviews and documentaries. Studies have concluded that isolated students tend to withdraw from their peers because of low social skills. The isolated student spends more time alone, less active and quiet in class and cannot participate in group activities, which causes the student to feel mider and to become self-absorbed and withdraw from his or her peers. As for the insulated " $r$ " factor in having a barrier to communicate with and being unaccustomed to social interaction with the
\end{abstract}


neighborhood, " $r$ " students withdraw from their peers and have no interest in following group activities asa social process.

\section{Keywords: Cause Factors, Students, Isolation}

\section{PENDAHULUAN}

Pendidikan yang diselenggarakan di sekolah diharapkan mampu membentuk siswa untuk dapat mengembangkan sikap, keterampilan dan kecerdasan intelektualnya agar menjadi manusia yang terampil, cerdas,serta berakhlak mulia. Pendidikan adalah suatu proses dalam rangka mempengaruhi siswa agar dapat menyesuaikan diri sebaik mungkin terhadap lingkungannya sehingga akan menimbulkan perubahan dalam dirinya yang memungkinkannya untuk berfungsi secara memadai dalam kehidupan masyarakat.

Fenomena ini sebagaimana di tegaskan bahwa sekolah sebagai suatu lembaga pendidikan formal, secara sistematis telah merencanakan bermacam lingkungan, yang menyediakan bermacam kesempatan bagi siswa untuk melakukan berbagai kegiatan belajar sehingga para siswa memperoleh pengalaman pendidikan sesuai kebutuhan.

Upaya mencapai harapan yang di kemukakan siswa memerlukan interaksi dengan sesama warga sekolah tersebut baik dengan sesama teman, guru, maupun staf sekolah lainnya. Tentu saja dalam berinteraksi tersebut harus sesuai dengan etika, norma dan aturan yang berlaku disekolah khususnya masyarakat pendidikan umum.

Bentuk interaksi tersebut dapat berupa kerjasama, sebagai contoh ketika sekolah mengadakan kegiatan ekstrakulikuler, siswa akan mengikutsertakan dalam berbagai cabang perlombaan seperti volly, sepak bola, basket dan lain-lan. Selain itujika dalam pergaulan kelompok siswa melakukan interaksi maka akan bisa memperoleh berbagai bahan dan kesempatan untuk berdiskusi serta peluangpeluang untuk memudahkannya dalam kegiatan belajar.

Sebagai contoh ketika dalam proses belajar ada salah satu siswa tidak memiliki buku atau bahan untuk belajar maka siswa tersebut bisa bertanya kepada temannya yang memiliki bahan dalam belajar. Sebaliknya jika siswa tersebut tidak melakukan interaksi maka akan tertinggal dalam proses belajar. Dengan 
adanya interaksi disekolah maka akan terbentuk kelompok pergaulan antar siswa. Diantara siswa tersebut belum tentu sukses dalam berinteraksi sering kali menemui hambatan dalam berinteraksi.

Berbagai cara siswa bersosialisasi sangat beraneka ragam. Ada yang memiliki keterampilan bersosialisasi dengan baik dan ada pula yang belum sesuai dengan etika, norma, budaya dalam berinteraksi. Siswa yang mempunyai keterampilan bersosialisasi dengan baik akan memiliki banyak teman dan diterima dalam lingkungannya.

Sebaliknya siswa yang tidak memiliki keterampilan bersosialisasi cenderung akan terisolir dari pergaulan sesama. Berbagai kasus terjadi di sekolah salah satunya berdasarkan berita yang dilansir dari www.tribunnews.com// pada tanggal 13 Februari 2020, di SMP Muhammadiyah Purworejo yang viral, dimana dalam kasus tersebut ada tiga orang siswa laki-laki merundung seorang siswi perempuan. Mereka menendang dan bahkan memukul si korbannya dengan gagang sapu sambil tersenyum menganiaya siswi tersebut. Korban yang tampak tidak berdaya hanya menundukkan kepala di mejanya sambil menangis. Selain itu masih banyak juga terjadi disekolah-sekolah.

Keadaan siswa tergolong terisolir tersebut dipengaruhi oleh berbagai faktor yang berbeda, ada dominan dan ada juga pengiring. Gejala perilaku sehari-hari pada umumnya menghindar dan menyendiri pada saat teman-temannya berkumpul baik didalam kelas maupun diluar kelas terutama pada jam istirahat. Hal ini sejalan dengan hasil penelitian menurut Ariani, dwi (2017) menunjukkan faktor penyebab siswa terisolir di kelas III Sd N 1 Pedes:(1) kondisi kesehatan siswa rendah sehingga menyebabkan siswa sulit untuk melakukan interaksidengan teman-temannya, (2) perhatian orang tua yang kurang kepada anak (3) siswa terisolasi tidak memiliki penampilan yang baik dan rapi (4) kebiasaan siswa yang kurang baik, contohnya seperti siswa jarang mengerjakan piket dan jarang mengerjakan perintah guru (5) kurangnya rasa tenggang rasa siswa (6) rendahnya rasa percaya diri siswa (7) tidak mampu menyesuaikan diri dengan lingkungan sosialnya. 


\section{METODOLOGI PENELITIAN}

Objek dalam penelitian ini adalah perilaku siswa " $R$ " yang terisolir di SMK PGRI 1 Palembang. Dalam metode pengumpulan data peneliti menggunakan teknik observasi, wawancara dan dokumentasi dimana peneliti melakukan wawancara dengan wali kelas, guru bimbingan dan konseling dan objek yang di teliti.Penelitian ini menggunakan metode kualitatif, metode penelitian adalah cara ilmiah untuk mendapatkan data dengan tujuan dengan kegunaan tertentu Sugiyono (2018:2).

\section{HASIL DAN PEMBAHASAN}

Tujuan penelitian ini yaitu untuk mengetahui faktor penyebab siswa yang terisolir. Penelitian ini diawali dengan melakukan observasi dan berdasarkan informasi dari guru bimbingan dan konseling terdapat salah satu siswa yang terisolir di kelas XII Akuntansi 2. Selanjutnya peneliti melakukan wawancara dengan wali kelas, guru bimbingan dan konseling dan siswa " $\mathrm{R}$ " yang terisolir.

Peneliti melakukan wawancara dengan wali kelas, guru BK dan siswa "R" diperoleh bahwa penyebab perilaku " $R$ " terisolir lebih sering menghabiskan waktu menyendiri, kurang aktif dan pendiam di kelas. " $R$ " seringkali mendapat penolakan dari teman-temannya pada saat guru membagikan kelompok dalam belajar. Peserta didik terisolir yang mengalami kesulitan berinteraksi sosial digolongkan ke dalam tiga kelompok menurut Hidayati (dalam amalia, dkk 2019) yaitu: (1) peserta didik yang ditolak oleh kelompoknya, (2) peserta didik yang diabaikan oleh kelompoknya, dan (3) peserta didik yang menolak bergabung dengan kelompoknya.

Dari hasil wawancara terdapat faktor penyebab " $R$ " terisolir, yaitu " $R$ " memiliki hambatan dalam berkomunikasi sehingga " $R$ " seringkali di bully oleh teman sekelasnya oleh sebab itu " $R$ " menarik diri, merasa minder dan kurang percaya diri dalam bergaul. Dampak yang di timbulkan akibat peserta didik terisolir akan mengalami tekanan baik itu dari luar maupun dari dalam diri sendiri, dan ini akan membawa dampak pada ketidak baikan individu. Sejalan dengan pendapat Hurlock dalam (wartini, dkk 2013) menyatakan bahwa pengaruh dari luar dalam pembentukan sosial siswa juga mempunyai peranan yang sangat penting bagi sikap sosial dan pola perilaku anak. 
Perilaku terisolir menunjukkan ketidakmampuan siswa berinteraksi dengan baik. siswa terisolir adalah siswa yang tidak memiliki teman dalam bergaul, jarang dipilih atau sering kali mendapat penolakan dari lingkungannya dan diasingkan akibat banyak penolakan dari pergaulan teman-teman sebayanya, tidak mempunyai minat untuk mengikuti kegiatan-kegiatan kelompok sebagai proses sosial. Hal ini sejalan dengan pendapat Kumalasari, (2017), Perilaku terisolir siswa adalah suatu sikap individu yang tidak dapat menyerap dan menerima norma-norma ke dalam kepribadiannya dan ia juga tidak mampu untuk berperilaku yang pantas atau menyesuaikan diri menurut tuntutan lingkungan yang ada.

\section{KESIMPULAN}

Berdasarkan hasil penelitian yang diperoleh melalui teknik observasi, wawancara dan dokumentasi dapat disimpulkan bahwa faktor penyebab siswa terisolir di SMK pgri 1 Palembang memiliki hambatan dalam bersosialisasi di lingkungan pergaulan teman sebaya.

Siswa terisolir adalah siswa yang tidak memiliki teman dalam bergaul, diasingkan, jarang dipilih serta seringkali mendapat penolakan dari lingkungannya. Adapun faktor penyebab siswa " $R$ " terisolir adalah hambatan dalam berkomunikasi serta tidak terbiasa bersosialisasi dengan lingkungan sekolah, akibatnya siswa "R" merasa minder dan menarik diri dari lingkungan pergaulan teman sebayanya serta tidak mempunyai minat untuk mengikuti kegiatan-kegiatan kelompok sebagai proses sosial

\section{DAFTAR PUSTAKA}

Amalia, Sri Rezeki, dkk. 2019. Analisis Peserta Didik Yang Terisolir di MAN 2 Pontianak. Program Studi Bimbingan dan Konseling FKIP Untan Pontianak.

Aryani, Dwi. 2017. Faktor Penyebab Siswa Terisolir Di Kelas III SD N 1 Pedes. S1 thesis, PGSD.

Kumalasari, Dyesi. 2017. Konsep Behavioral Therapy Dalam Meningkatkan Rasa Percaya Diri Pada Siswa Terisolir. HISBA: Jurnal Bimbingan Konseling dan Dakwah Islam, Vol. 14, No. 1 
Sugiyono. 2018. Metode Penelitian Kuantitatif, Kualitatif dan R\&D. Bandung: CV. Alfabeta.

Wartini, dkk. 2013. Karakteristik Belajar Siswa Terisolir. Jurnal Ilmiah Konseling, Vol.2 No.1.

Tribunnews.com. 2020. Siswa SMP Purworejo viral. 